\title{
RANCANG BANGUN SISTEM KOMPUTERISASI AKUNTANSI PT. PITA TRANS LINE
}

\author{
Rina Nugrahwati ${ }^{1)}$, Mega Orina Fitri ${ }^{3)}$ \\ ${ }^{1,2,3}$ Jurusan Sistem Informasi, Fakultas Sains dan Teknologi, UIN Alauddin \\ ${ }_{1,2,3}$ Samata Kab. Gowa (Kampus 2) \\ E-mail: rina.nugrahwati@gmail.com ${ }^{1)}$,yusran.bobihu@uin-alauddin.ac.id ${ }^{2)}$,mega.orina@uin-alauddin.ac.id ${ }^{3)}$
}

\begin{abstract}
Abstrak - Proses pengelolaan keuangan pada PT. Pita Trans Line dikatakan belum terkomputerisasi, dengan mengandalkan kertas untuk pengarsipan data keuangan, sehingga sering terjadi kesalahan dalam proses perhitungan membuat kinerja pegawai kurang efisien, dan untuk mendapatkan informasi keuangan tersebut membutuhkan waktu yang lama. Hal ini merupakan suatu hambatan sehingga bila staf keuangan sedang berada di luar perusahaan, maka tidak bisa dilakukan transaksi dan membuat pimpinan sulit mengetahui keadaan keuangan secara cepat. maka perlu dibangun sistem informasi akuntansi yang dapat memudahkan kinerja bagian keuangan dan pimpinan dalam proses pengolahan data keuangan dan dapat memberikan informasi keuangan yang lebih sistematis. Metode pengembangan aplikasi ini yaitu metode waterfall, sedang metode pengumpulan data yang digunakan yaitu observasi, wawancara, dan studi literatur. Adapun metode perancangan yang digunakan adalah Data Flow Diagram (DFD), sedang metode pengujian menggunakan Blackbox. Bahasa pemrograman yang digunakan adalah $P H P$ dan dbms MySQL. Sistem ini mencakup beberapa konten yaitu beranda, master data, serta pelaporan. Hasil dari pengujian Blackbox menyimpulkan bahwa fungsi yang diharapkan semuanya berhasil sesuai dengan yang diinginkan. Dengan dibangunnya sistem informasi akuntansi ini maka dapat memudahkan kinerja staf keuangan dalam mengelola aktivitas dan menganalisa laporan keuangan pada PT. Pita Trans Line dengan lebih baik.
\end{abstract}

Kata Kunci : Sistem Infomasi, Akuntansi, transportasi, PHP, MySQL, DFD, Black Box

\section{Pendahuluan}

Di Indonesia, operator bus biasanya dikenal dengan nama PO (Perusahaan

Otobus). Operator bus adalah perusahaan yang melayani jasa angkutan bus baik penumpang maupun barang. Bus merupakan angkutan umum yang dapat memuat 27 penumpang. Tapi kini ada juga bus yang berukuran besar yang bisa memuat hingga 35 penumpang. Di Indonesia terdapat banyak Perusahaan Otobus (PO) juga di kota terpenting di Indonesia timur, Makassar. Salah satu PO yang berada di Makassar adalah PT. Pita Trans Line atau yang biasa dikenal dengan nama PO. PIPOSS.

PT. Pita Trans Line beralamatkan di Jl. Kima Raya Makassar, merupakan salah satu perusahaan yang bergerak dibidang jasa pelayanan transportasi yang menangani berbagai hal yang berkaitan dengan transportasi seperti penjualan tiket, pengiriman barang, serta hal lain yang berkaitan dengan layanan transportasi. Oleh sebab itu, PT. Pita Trans Line memiliki beberapa data yang membutuhkan pengolahan yang berbasis komputerisasi agar informasi yang dihasilkan bisa lebih maksimal. Salah satu hal yang membutuhkan pengolahan data secara komputerisasi adalah data keuangan, dimana data keuangan merupakan salah satu asset sangat penting yang membutuhkan proses pengolahan data yang baik.

Berdasarkan hasil survey yang telah dilakukan, proses pengolahan data keuangan pada PT. Pita Trans Line masih dilakukan dengan pencatatan pada

sebuah buku yang menyebabkan sering terjadi kesalahan pada proses komputasi atau perhitungan yang membuat kinerja pegawai kurang efisien, karena setiap kali harus menelusuri lagi, mencari 
dimana letak kesalahan yang telah dibuat.

PT. Pita Trans Line banyak melakukan pencatatan transaksi dan proses perhitungan akuntansi setiap hari, dimana data-data yang ada disimpan dalam bentuk arsip menyebabkan proses pencarian data serta proses pembuatan laporan membutuhkan waktu yang cukup lama. Oleh karena itu, pengolahan data keuangan tersebut dikatakan belum sistematis, akibatnya laporan keuangan yang dihasilkan tidak tepat. Hal tersebut membuat pimpinan sulit mengetahui keuangan perusahaan dikarenakan belum diterapkannya sistem akuntansi

Permasalahan tersebut tentu memerlukan sistem pengolahan keuangan yang cepat dalam memproses data menjadi sebuah informasi. Informasi menjadi kebutuhan mutlak bagi setiap organisasi, baik organisasi pemerintah maupun swasta. Keseluruhan kegiatan organisasi pada dasarnya membutuhkan sistem informasi. Oleh karena itu, informasi menjadi bagian yang sangat penting untuk mendukung proses kerja seorang akuntan. Dari sisi ilmu pengetahuan, Akuntansi adalah ilmu informasi yang mencoba mengkonvensi bukti dan data menjadi informasi dengan cara melakukan pengukuran atas berbagai transaksi dan akibatnya yang dikelompokkan dalam account, perkiraan atau pos keuangan seperti aktiva, utang, modal, pendapatan dan biaya.

Dengan dibangunnya sistem informasi akuntansi berbasis web ini, diharapkan dapat membantu pegawai pada PT. Pita Trans Line agar dapat membuat jurnal secara praktis dan cepat pada transaksi yang terjadi. Dapat disimpulkan bahwa permasalahan yang dihadapi saat ini oleh pegawai Piposs adalah proses perhitungan akuntansi yang masih manual, yaitu pada penjurnalan transaksi, serta pembuatan laporan keuangan. Oleh karena itu perlunya diterapkan sistem informasi akuntansi berbasis website sehingga laporan yang dihasilkan merupakan informasi yang berkualitas.

Berdasarkan hal tersebut maka dilakukan penelitian lebih lanjut dan mengangkat judul : "Rancang Bangun Sistem Informasi Akuntansi Berbasis Web Pada PT. Pita Trans Line". Informasi akuntansi yang dihasilkan dapat memenuhi kebutuhan akuntansi berupa laporan keuangan yang dapat diakses dimana saja, sehingga meghasilkan laporan keuangan yang akurat dan sistematis.

\section{Metodologi Penelitian}

Jenis penelitian yang digunakan adalah metode kualitatif. Dimana hanya mendeskripsikan data apa adanya dan menjelaskan data atau kejadian dengan kalimat-kalimat penjelasan secara kualitatif. Jenis penelitian kualitatif, informasi yang dikumpulkan dan diolah harus tetap objektif dan tidak dipengaruhi oleh pendapat peneliti sendiri (Husein , 2008). Adapun lokasi penelitian ini dilakukan pada PT. Pita Trans Line yang beralamat di Jalan Kima Raya Kota Makassar.

\section{Pendekatan Penelitian}

Penelitian ini menggunakan pendekatan penelitian saintifik yaitu pendekatan berdasarkan ilmu pengetahuan dan teknologi.

\section{Sumber Data Penelitian}

Sumber data pada penelitian ini adalah menggunakan Library Research yang merupakan cara mengumpulkan data dari beberapa buku, jurnal, skripsi, tesis maupun literatur lainnya yang dapat dijadikan acuan pembahasan dalam masalah ini. Keterkaitan pada sumber-sumber data online atau internet ataupun hasil dari penelitian sebelumnya sebagai bahan referensi bagi peneliti selanjutnya.

\section{Metode Pengumpulan Data}

Untuk memperoleh data yang relevan dengan masalah yang dibahas, penelitian menggunakan metode pengumpulan data sebagai berikut:

a. Observasi Observasi merupakan teknik penelusuran fakta dimana analis sistem

berpartisipasi atau melihat seseorang melakukan aktivitas untuk mempelajari sistem (Whitten, 2004:245). Observasi yang dilakukan adalah dengan mengamati secara langsung kondisi objek penelitian untuk menentukan perlu tidaknya sistem tersebut dirancang.

Sasaran dari observasi adalah : 
1. Mengetahui sistem keuangan yang telah berjalan pada PIPOSS.

2. Mengetahui proses akuntansi yang ada pada PIPPOSS.

teknik penelusuran fakta dilakukan dengan analis sistem mengumpulkan informasi dari individuindividu melalui interaksi face to face. Pada tahap ini mengadakan tanya jawab kepada pihak yang ada hubungannya dengan objek penelitian. Sasaran pada tahapan ini adalah:

1. Mendapatkan informasi tentang sistem keuangan di PIPOSS.

2. Pemanfaatan teknologi informasi pada bagian keuangan PIPOSS.

3. Rencana penggunaan Sistem Informasi Akuntansi berbaisis web untuk menunjang keuangan di PIPOSS.

\section{Instrumen Penelitian}

Dalam proses pengumpulan data yang akan dilakukan, kelengkapan alat bantu juga berperan penting terhadap kelancaran proses pengumpulan data yang dibutuhkan. Dalam mengumpulkan datadata penulis membutuhkan alat bantu, yaitu: a. Kebutuhan Perangkat Keras

Perangkat keras yang digunakan untuk mengembangkan dan mengumpulkan data pada aplikasi ini adalah sebagai berikut :

\section{. 1) Laptop Acer}

2) Memory $2 G B$

3) Processor $1.0 \mathrm{Ghz}$

4) Harddisk $500 \mathrm{~GB}$

Kebutuhan Perangkat Lunak Adapun perangkat lunak yang digunakan dalam aplikasi ini adalah:

1. Sistem Operasi, Windows 7 Ultimate 32-bit

2. Web browser

3. AppServer

4. $M y S Q L$
5. Macromedia Dreamweaver 8

6. $P H P$

7. ClickChart Diagram Flowchart software

8. Microsoft Office Visio 2007

\section{Teknik Pengolahan dan Analisis Data}

\section{Pengolahan Data}

Pengolahan data diartikan sebagai proses mengartikan data-data lapangan yang sesuai dengan tujuan, rancangan, dan sifat penelitian. Metode pengolahan data dalam penelitian ini yaitu:

a. Reduksi Data adalah mengurangi atau memilahmilah data yang sesuai dengan topik dimana data tersebut dihasilkan dari penelitian.

b. Koding Data adalah penyesuaian data diperoleh dalam melakukan penelitian kepustakaan maupun penelitian lapangan dengan pokok pada permasalahan dengan cara memberi kode-kode tertentu pada setiap data tersebut.

\section{Analisis Data}

Dalam penelitian ini, metode yang digunakan penulis adalah metode analisis kualitatif. Analisis kualitatif adalah prosedur penelitian yang bermaksud untuk memahami fenomena tentang apa yang dialami oleh subjek penelitian misalnya perilaku, persepsi, motivasi, tindakan, dll. Secara holistic, dengan cara deskriptif dalam bentuk katakata dan bahasa (Moelong, 2002).

\section{Hasil dan Pembahasan}

Sistem Informasi Akuntansi Berbasis Web Pada PT.Pita Trans Line diregister melalui domain http://www.siapiposs.esy.es/.

1. Implementasi Antarmuka

(Interface)Implementasi antarmuka dari perangkat lunak dilakukan berdasarkan 
rancangan yang telah dilakukan. Implementasi ditampilkan dari screenshoot dari halaman website yang digunakan sebagai alat dan bahan penelitian yang telah dirincikan pada Bab IV.

\section{a) Antarmuka Form Login}

Gambar V.1 Form LoginForm Login merupakan tampilan pertama yang muncul pada saat program

dijalankan, dimana pada form ini para pengguna atau operator akan diminta untuk memasukkan User ID beserta Passwod masing-masing berdasarkan type.

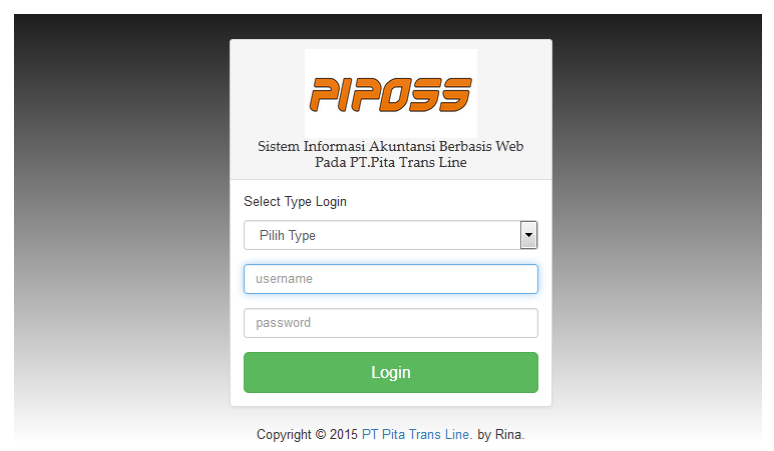

\section{b) Antarmuka Tampilan Home}

Gambar V.2 Tampilan HomePada layar Home, ditampilkan menu utama terdapat menu priode, akun,

transaksi, jurnal umum, dan menu laporan yang terdiri dari laporan neraca, laporan buku besar, laporan laba rugi, dan laporan ekuitas. Dan terletak 4 menu teratas berguna untuk melihat secata cepat detail dari menu-menu tersebut. Tampilan home diatas terdapat keterangan "anda login sebagai admin (bagian keuangan)".

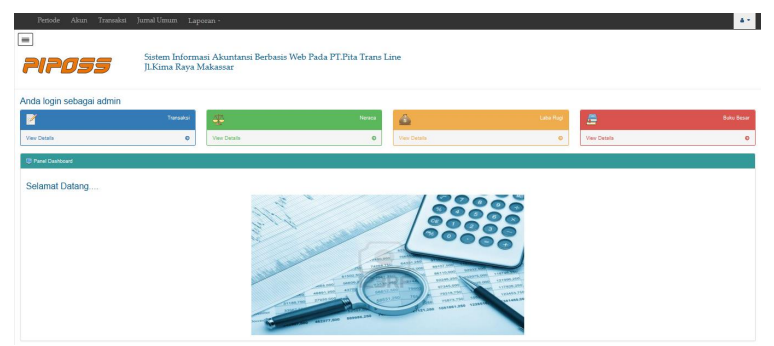

c) Tampilan halaman login pimpinan

Gambar V.3 Tampilan halaman login pimpinan Pada halaman login untuk pimpinan, yang ditampilkan hanya menu laporan neraca, laporan buku besar, laporan laba rugi, dan laporan ekuitas. Pimpinan

hanya dapat melihat laporan tersebut.

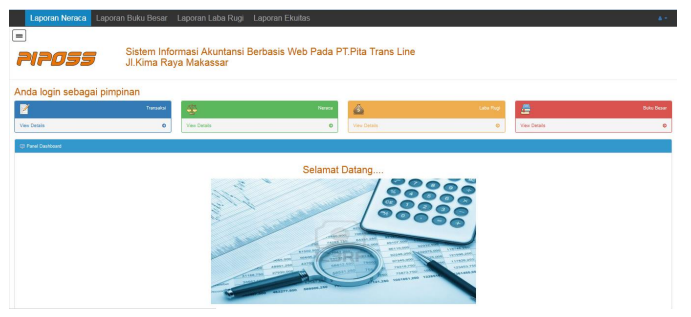

d) Antarmuka Tampilan Data Periode

Gambar V.4 Tampilan Data Priode Pada tampilan data periode, terdapat tabel priode yang terdiri dari kolom

no, kode, nama, dan action. Dimana action terdiri dari pilihan edit dan hapus. e) Antarmuka Tampilan Data Akun

Gambar V.5 Tampilan Data Akun Pada tampilan data akun, ditampilkan tabel info akun dengan kode dan

akun-akun(perkiraan) beserta tipenya.

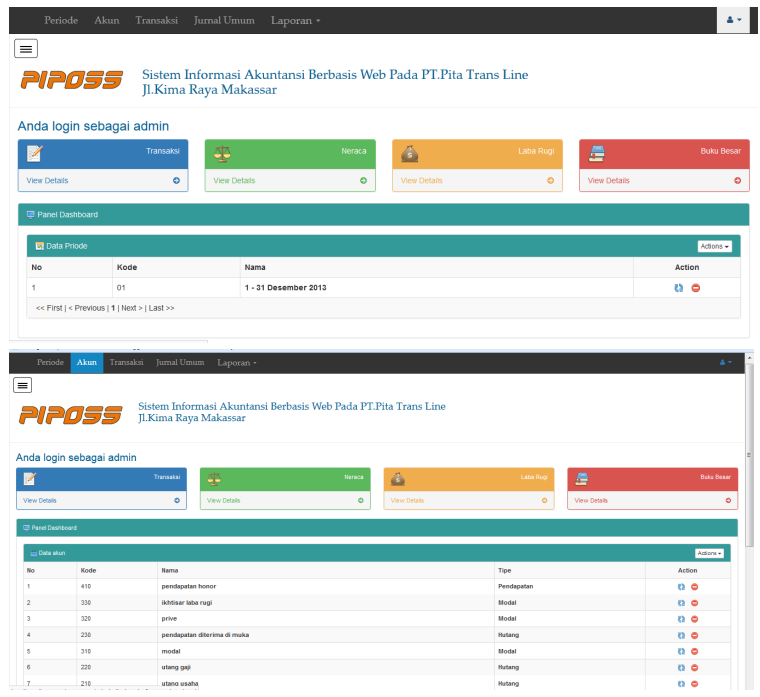

f) Antarmuka Tampilan Data Transaksi

Gambar V.6 Tampilan Data Transaksi

Pada tampilan data transaksi, terdapat tabel data transaksi yang terdiri dari kolom No, Priode , No Transaksi, Nama Transaksi, Jumlah, Tanggal Transaksi dan Action. Pada kolom "actions", ada dua pilihan, yaitu pilihan tambah dan search. Form data transaksi untuk mencatat data-data transaksi 
yang terjadi sebelum melakukan penjurnalan dalam periode tertentu. Gambar diatas adalah data transaksi pada periode Desember 2013, disertai dengan tanggal terjadinya. Adapun tombol search jika ingin mencari data yang ingin dilihat sebelumnya.

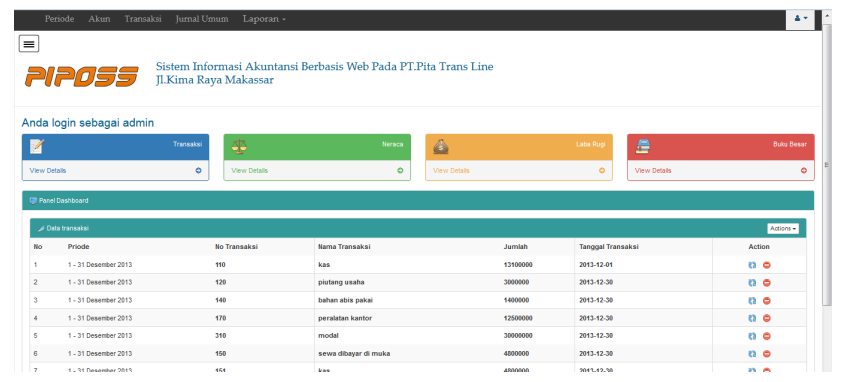

\section{g) Antarmuka Tampilan Data Jurnal}

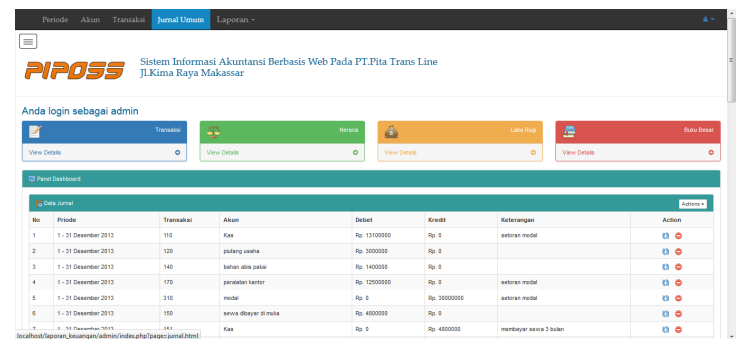

Gambar V.7 Tampilan Data Jurnal

Pada tampilan data jurnal, ditampilkan tabel data jurnal yang terdiri dari kolom No, Transaksi, Priode, Akun, Debet, Kredit, keterangan, Action. Form data jurnal umum untuk menampilkan transaksi yang dicatat sebelumnya, dengan melihat akun-akun apa yang terjadi, letak posisi menurut tipenya(debet kredit) disertai keterangan. Nilai pada kolom debet dan kredit harus sama. Untuk menambah data pada jurnal dapat dilakukan dengan memilih action 5 " “tambah".

\section{h) Antarmuka Form Laporan Neraca}

\section{Gambar V.8 Form Laporan Neraca}

Pada form laporan neraca, user dapat memilih priode untuk menampilkan informasi laporan neraca. Terdiri dari kolom akun, total debet dan kredit. Neraca merupakan laporan yang berfungsi untuk menunjukkan posisi keuangan pada akhir periode.

i) Antarmuka Cetak Laporan Data Neraca

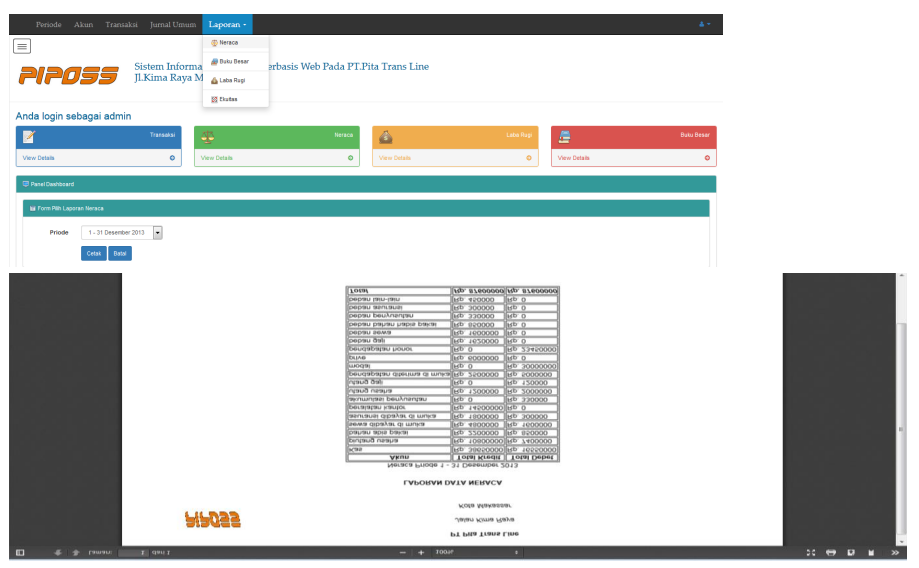

Gambar V.9 Cetak Laporan Data Neraca

Laporan Data Neraca Saldo menampilkan ringkasan laporan buku besar transaksi pada masing-masing akun. Kemudian jumlah saldo antara keduanya harus balance(seimbang).

\section{j) Antarmuka Form Laporan Buku Besar}

Gambar V.10 Form Laporan Buku Besar

Pada form laporan buku besar, user dapat melihat transaksi-transaksi yang sebelumnya telah di-inputkan di jurnal umum dimana buku besar ditampilkan berdasarkan kelompok akun. Kemudian menekan tombol cetak jika ingin mencetak laporan dari masing-masing akun yang terjadi pada priode tersebut.

\section{k) Antarmuka Cetak Laporan Data Buku Besar}

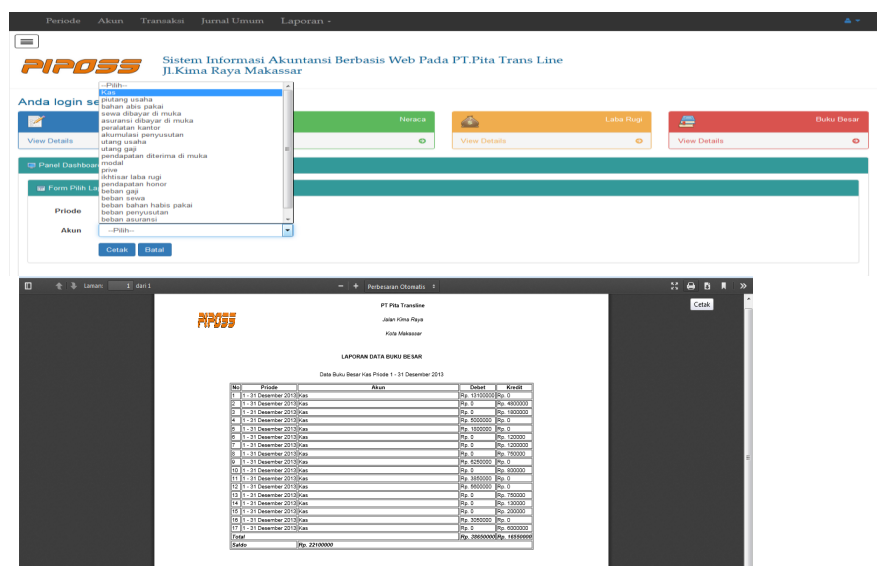

Gambar V.11 Cetak Laporan Data Buku Besar

Pada laporan diatas, buku besar yang ditampilkan adalah transaksi yang terjadi pada kelompok akun yaitu akun Kas di priode Desember 2013 dengan menampilkan no, priode, debit dan kredit serta kolom saldo. Dan menampilkan saldo akhir dari masing-masing akun yang dipilih. 
1) Antarmuka form Laporan laba Rugi

Gambar V.12 Form Laporan Laba Rugi Pada form pilih laporan laba rugi, user dapat melihat laba atau rugi dengan

memilih periode. m) Antarmuka Cetak laporan Data Laba Rugi

Gambar V.12 Cetak Laporan Data Laba Rugi
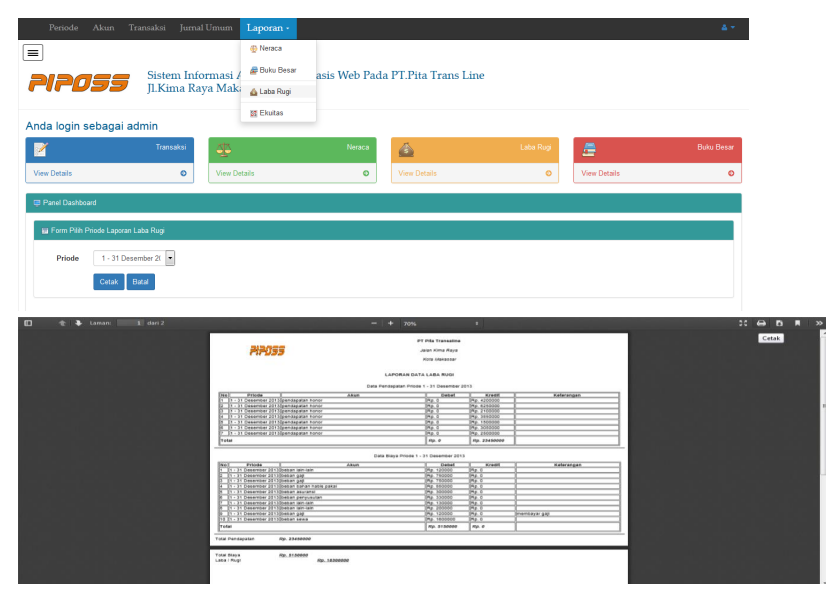

Laporan laba rugi menunjukan perusahaan mengalami kerugian dimana laporan tersebut menghasilkan detail pendapatan, detail beban. Laporan menghasilkan laba jika pendapatan lebih besar daripada beban dan sebaliknya jika pendapatan lebih sedikit daripada beban maka dikatakan rugi.

Antarmuka Form Laporan Perubahan Modal

Gambar V.13 Form Laporan Perubahan Modal Pada form Laporan Ekuitas, user dapat melihat transaksi jurnal yang terjadi dengan memilih priode. Kemudian menekan tombol cetak jika ingin

mencetak laporan tersebut.

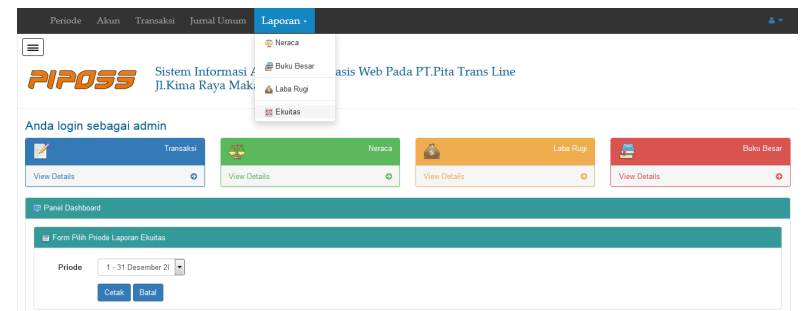

18. Antarmuka Cetak Laporan Data Perubahan Modal
Gambar V.14 Cetak Laporan Data Perubahan Modal Pada data laporan perubahan modal ditampilkan laba atau rugi yang diterima oleh Piposs dan pengambilan pribadi(prive) yang dilakukan. Laba akan menambah modal sedangkan rugi dan pengambilan pribadi akan mengurangi modal.

\section{KESIMPULAN}

Kesimpulan yang dapat diambil dari penelitian ini adalah Sistem Informasi Akuntansi Berbasis Web pada PT. Pita Trans Line dapat meminimalkan kesalahan pada proses perhitungan, memudahkan dan mempercepat proses pencarian data dengan adanya pembuatan laporan keuangan yang sistematis. Dari hasil pengujian BlackBox, sistem informasi akuntansi berbasis web ini berhasil menjalankan fungsinya sesuai yang diharapkan, sementara dari hasil wawancara/kuisioner mengatakan bahwa aplikasi ini dapat memenuhi kebutuhan akuntansi berupa laporan keuangan yang dapat diakses secara online.

\section{DAFTAR Pustaka}

Amsyah, Zulkifli. Manajemen Kearsipan. Jakarta: PT Gramedia Pustaka Utama, 1993.

Andajani, Aroem. Membangun Aplikasi Berbasis Web. Yogyakarta : Adicita Karya Nusa, 2011.

Arian, Tegar. "Pengertian website". http://tegararian.blogspot.com/pengertianwebsite.html (akses 2 juli 2015).

Departemen Agama. Al Qur'an dan Terjemahannya. Jakarta: Departemen Agama, 1983.

Departemen Agama RI.Al Qur'an Al Baqarah Dan Terjemahannya. Jakarta: CV. Nala Dana, 2007.

Departemen Agama RI, Al-Qur'an Al-Karim Dan Terjemahannya. Bandung: PT. Sygma Examedia Arkanleema, 2007.

Fathansyah, Ir. Basis Data. Yogyakarta: Graha Ilmu, 2011. 
Fathurrahmi, Ismi Islamia. "Pengertian, Perbedaan White Box dan Black Box Testing". Official Website of Ismi Islamia Fathurrahmi. http:// ismimiitsme.blogspot.com/2013/10/penge rtian-dan-perbedaan-white-box.html (13 Oktober 2014).

Fahmi, Irham. Analisis Kinerja Keuangan. Bandung: Alfabeta, 2012. Febrian, Jack. Kamus Komputer dan Teknologi Informasi. Bandung: Informatika

Bandung, 2007. Hall, James.A. Accounting Information Systems (3rd ed.). Skripsi Sarjana Faculty

Publishing, 2001. Haryono, AL. Dasar-Dasar Akuntansi Edisi Ke-6. Yogyakarta: Aditya Media, 2005.

Husein, Muh Fakri dan Wibowo. Konsep Sistem Informasi. Bandung: Informatika, 2008.

Husein, Umar. Cara Mudah Menyusun Skripsi dan Tesis Dilengkapi Dengan Contoh Lengkap Draft Laporan Untuk Dikritis. Jakarta: Raja Grafindo Persada, 2008.

Jogiyanto. Analisis dan Desain Sistem Informasi; Pendekatan Terstruktur Teori dan Praktek Aplikasi Bisnis.Yogyakarta: Andi Offset, 2011.

Jogiyanto. Tutunan Praktis Membangun Sistem Informasi Akuntansi. Yogyakarta: Andi Offset, 2005.

Jogiyanto. Analisis dan Desain Sistem Informasi; Pendekatan Terstruktur Teori dan Praktek Aplikasi Bisnis.Yogyakarta: Andi Offset, 2011.

Jumingan. Analisis Laporan Keuangan. Jakarta: Bumi Aksara, 2010. Kadir, Abdul. Belajar Database Menggunakan MySQL. Yogyakarta: C.V Andi

Offset, 2008.

Kadir, Abdul. Dasar Perancangan dan
Implementasi Database Relasional, Edisi I. Yogyakarta: Andi Offset, 2009.

Kadir, Abdul. Dasar Pemrograman Web Dinamis Menggunakan PHP. Yogyakarta: Andi Offset, 2003.

Kartika, Dyota Swasti. Rancang Bangun Sistem Informasi Akuntansi Berbasis Web Pada Koperasi Simpan Pinjam Bougenville Surabaya. Skripsi Sarjana Universitas Pembangunan Nasional Jawa Timur, 2012.

Kusrini, Koniyo, dan Andi. Tuntunan Praktis Membangun Sistem Informasi Akuntansi Dengan Visual Basic \& Microsoft Sql Server. Andi: Yogyakarta, 2007.

Lucas, Hendry. Analisa dan Desain Sistem Informasi. Jogjakarta : Castle Books, 2005.

Mala, DoankBinKokom. "Diagram Alir Dokumen (Flow Map)", Blog Mala Doankbi kokom. http://berbagi-ilmumifa309.blogspot.com/2012/06/diagram alir dokumen-flow-map.html (20 Maret 2015).

Moelong, J. Lexi. Metodologi Penelitian Kualitatif. Bandung: Remaja Karya, 2002. Mulyadi. Sistem Akuntansi. Salemba Empat: Jakarta, 2008.

Mulyanta, Agus. Sistem Informasi Konsep dan Aplikasi. Yogyakarta: Andi Offset, 2009.

Pardosi, Mico. Pengenalan Internet . Surabaya : PT. Indah Anggota IKAPI, 2004. Pressman, Roger S. Rekayasa Perangkat Lunak Pendekatan Praktisi (Buku satu),

Yogyakarta: Andi Offset, 2009.

Pressman, Roger S. Software Engineering. Yogyakarta: Sumber Ilmu, 2001.

Pohan, Husni I. Membuat Sistem Informasi Penjualan Berbasis Web dengan PHP dan MySQL. Yogyakarta: Gava Media, 2011. 
Rasjid, Sulaiman. Fiqh Islam. Bandung : Sinar Baru Algensindo . 1994

Shihab, M. Quraish. Tafsir Al-Mishbah : Pesan, Kesan, Keserasian Al-Qur'an, Vol 8 Dan Vol 10, Edisi Baru. Jakarta : Lentera Hati, 2009.

Sidik, Betha. Pemrograman Web dengan PHP. Bandung : Informatika Bandung, 2014.

Simarmata, Janner. Rekayasa Perangkat Lunak. Yogyakarta: Andi Offset, 2010. Supardi, Yanuar. Analisis dan Desain Sistem Informasi. Jakarta: PT. Gramedia

Pustaka Utama, 2010.

Sutabri, Tata. Analisa Sistem Informasi. Yogyakarta: Andi Offset, 2011.

Sutarman, Membangun Aplikasi web dengan PHP dan MySQL. Yogyakarta: Graha ilmu, 2003.

Sutrisno. Akuntansi Proses Penyusunan Laporan Keuangan. Yogyakarta: Ekonisia, 2008

Suwikno, Dwi. Ayat-ayat Ekonomi Islam. Yogyakarta : Pustaka Pelajar. 2010. Syafii, M. Panduan Membuat Aplikasi Database dengan PHP 5. Yogyakarta: Andi,

2005.Warren, dkk. Prinsip-prinsip Akuntansi. Jakarta: Penerbit Erlangga, 2008. Whitten, Jeffrey . System Analysis And Design Methods. USA : McGraw-Hill, 2004. 